\title{
The Extent and Nature of Bullying in a Christian School
}

\author{
Brian C. Hazeltine \\ Cornerstone University \\ David A. Hernandez \\ Walden University
}

\begin{abstract}
Bullying is a problem that has been studied in schools worldwide, but there is little research on bullying within Christian schools, a dearth which may stem from the assumption that Christian schools teach character traits that are inimical to bullying. Yet understanding the extent and nature of bullying in Christian schools may lead to a better understanding of ways to address the problem in all schools. Guided by social identity theory, which allowed for a focus on moral and character development, this study examined the extent and nature of bullying among 347 students in Grades 3 through 10 in a Christian school. Research questions addressed differences in bullying behaviors related to gender, grade, division, and the number of years a student has attended a Christian school. Data were analyzed from responses to the Olweus Bullying Questionnaire. One-way analysis of variance, chi-square, and $t$ tests indicated statistically significant differences in bullying behaviors based on gender, division, and years attending the school. Results indicated that girls were bullied more frequently than boys and by means of exclusion, rumors, sexual comments, and cyberbullying. Boys were more likely to bully than girls, and boys bullied primarily in physical ways and used racial comments more often than did girls. Bullying decreased from elementary to high school grades. The results of this study may be used to promote positive social change by alerting Christian school educators to the problem of bullying in their schools and by assisting all educators in developing gender-specific programs to minimize the problem of bullying in general.
\end{abstract}

Keywords: bullying, social identity theory, gender

\section{Introduction}

Bullying is a widespread problem that appears in schools at all grade levels and in every country where it has been studied. Researchers have studied it thoroughly in many settings and occasionally private or religious schools have been included, but a thorough review of the literature revealed no disaggregated data pertinent to bullying in Christian schools and no studies of bullying specifically in this context. Historically, Christian schools have demonstrated a strong commitment to the development of personal character and caring communities. These values are antithetical to those inherent in bullying, which suggests that the pattern of behaviors reported in these schools would be different from that observed in other schools. The purpose of this preliminary study was to determine the extent and nature of bullying within a Christian school and to determine whether there are significant differences in bullying behaviors based on gender, grade/division, and the number of years attending a Christian school. 
Despite various interventions to reduce all forms of violence in schools, the problem of bullying in schools persists. Olweus (2013) stated that over $17 \%$ of students in U.S. schools reported being verbally bullied in 2010, and Beaty and Alexeyev (2008) reported that bullying affects up to $70 \%$ of students in some way. Moreover, school aggression transcends the school environment and correlates with criminal behavior later in life (Fox, Elliott, Kerlikowske, Newman, \& Christeson, 2003; Theriot, Dulmus, Sowers, \& Bowie, 2004; Whitted \& Dupper, 2005). Many factors contribute to the problem of bullying, including the home environments of both bullies and victims, their academic achievement, and their social relationships (Dake, Price, \& Telljohann, 2003; Harlow \& Roberts, 2010).

Bullying begins in the primary grades with $26 \%$ of primary students reporting that it occurs on a daily or weekly basis; it rises in the middle school grades where $43 \%$ of students report it, and then bullying declines in the secondary school where $25 \%$ of students report it (DeVoe, Peter, Noonan, Snyder, \& Baum, 2005). Bullying appears to peak at about eighth grade for boys and ninth grade for girls. Cardoso (2007) stated that bullying "declines precipitously" after seventh grade (p. 65). The incidence of bullying is also related to maturation, with increased risk for children who reach puberty earlier (Pepler et al., 2006). There is a definite pattern of increased bullying as students enter middle school, but simultaneously the victimization rate declines with age (Craig et al., 2009). This suggests that more middle school students get involved in bullying, but they target a smaller group of victims.

Bullying is more common among males (Cardoso, 2007; Delfabbro et al., 2006), a pattern that Craig et al. (2009) found repeated in all 40 countries that they studied. One possible explanation for this pattern may be described in Zigarelli's (2002) study of character development. Zigarelli found that teen boys showed notably less evidence of compassion than girls. In early studies, researchers noted that boys tend to use physical aggression more than girls, while girls are more likely to use relational aggression such as gossip, rumor, and manipulation of friendships (Borg, 1999; Gabel, 2007; Olweus, 2003). On the other hand, Seals and Young (2003) discovered a somewhat more subtle distinction, reporting that physical bullying did not differ by gender, but that verbally, boys were more likely to use threats, while girls were more likely to resort to name-calling. They also found that girls were more likely to employ exclusion. More recently, researchers found higher use of physical aggression by boys but no significant differences between the genders for relational bullying (Lansford et al., 2012).

When perpetrators are considered, girls are bullied equally by both genders, but boys are primarily bullied by boys (Gabel, 2007). Girls and younger students were more likely than boys or older students to seek help from parents, friends, or teachers when bullied (Hunter, Boyle, \& Warden, 2004). There is no research-based consensus relating gender to defending behaviors, but the majority of studies indicated that girls are somewhat more likely to defend a victim than boys (Oh \& Hazler, 2009; Porter, 2009).

One effort to explain the role of the school and peer group in relation to bullying behavior is that of social identity theory (SIT), which Duffy and Nesdale (2009) described as

a theory of inter-group behavior, which proposes that individuals are motivated to achieve and maintain a positive social identity. According to SIT, this goal is accomplished by gaining membership in, and identifying with, groups that are perceived to be positively distinctive or comparatively superior to other groups. (p. 123) 
Once an individual has identified with a particular group, that group begins to exert an influence on the individual's behavior through its norms. In the context of bullying, it means that bullying decreases when the group views it as antinormative (Duffy \& Nesdale, 2009). Previous studies have found that this influence is evident at the classroom level (Salmivalli \& Voeten, 2004) and the friendship level (Duffy \& Nesdale, 2009). This study sought to extend these findings by examining the impact of group norms on behavior at the school level, specifically a Christian school with an intentional approach to values and character development.

The goal of character education in general and Christian school education in particular is to produce virtues that should eliminate bullying from the school scene (Bassett \& Baumann, 2003; Lickona, 2004; Schindler, 1995; Stronk, 2003). Both leading character education programs and Christian school philosophy view the development of virtue as requiring a comprehensive, schoolwide effort (Braley, 1995; Hollingshead, Crump, Eddy, \& Rowe, 2009; Lee, 2003). Others have noted the importance of the school culture and its broader community in sending a consistent message in this regard (Craig \& Pepler, 2007; Long \& Alexander, 2010). Recognizing that Christian schools have been involved in a unique form of character education for many years (Brown, 1995), we investigated whether students in a Christian school would report fewer incidents of bullying.

Whether the goal is promoting character or reducing violence, there seems to be agreement that a comprehensive approach involving everyone in the school community is required (Battistich, 2008). Christian schools generally take a comprehensive stance toward education and promote values and character qualities that should mitigate bullying (Brown, 1995; Edlin, 2003; Lickona, 2004). Moreover, these schools employ staff who believe in these values and agree to promote them within the classroom, on the school grounds, and at school events.

The purpose of this study was to examine the extent and nature of bullying in a Christian school to determine the effects of gender, grade/division, and years attending the school on the kinds of bullying reported, the location where it occurs, and whether it is reported. We were particularly interested in whether length of time enrolled in the Christian school would make a significant difference in bullying behaviors. Additionally, the goal was to determine whether the patterns of bullying were different from those observed in a similar study by Cardoso (2007) in public schools. However, determination of statistically significant differences with Cardoso's study was not possible because the data were not available for reanalysis. Therefore, we limited our comparison to observing differences in percentages.

\section{Method}

The setting for this study was a large, two-campus Christian school in Michigan. All staff and parents in this school had signed the agreement of the school's statement of faith and code of conduct. The school administered the survey in May of 2012 using the paper-and-pencil version of the Olweus Bullying Questionnaire (Olweus, 2007). Parents and students were informed of the voluntary nature of the survey, and no personally identifiable information was obtained. Students

completed the survey under standard testing conditions in their classrooms. The school later released the data to the researchers to analyze. The independent variables were the grade, division, gender, and years attending a Christian school. The dependent variables were (a) the 10 kinds of bullying behaviors (verbal, exclusion, physical, rumors, damage to property, threats, racial comments, sexual comments, cyberbullying, and other), (b) the location where bullying occurred, and (c) how students reported these events to adults. 


\section{Sample}

Table 1 displays a breakdown of the participants by gender, and includes an additional summary by division, grade, ethnicity, and years in a Christian school. A total of 347 out of 375 students in Grades 3 through 10 completed and returned the survey, which represents a response rate of 91.8\%-190 males (55\%), 156 females (45\%), and one student who did not specify a gender. By division, $19.3 \%$ of the participants were elementary students with a response rate of $94.4 \%, 36.3 \%$ were middle school students with a response rate of $95.5 \%$, and $44.4 \%$ were high school students with a response rate of $86.4 \%$. A large majority of the participants (72.5\%) were European American.

\section{Instrumentation and Scale Reliability}

Response choices to the survey items (sample items from the questionnaire can be downloaded from http://www.violencepreventionworks.org/public/document/olweus_bullying_questionnaire_sample.pdf) on bullying were measured on a 5-point Likert-style frequency scale, with $0=$ it has not happened to me in the past couple of months and $4=$ several times a week. Students were asked to constrain their responses to the frequency with which the incidents of bullying occurred over the previous 2-month period. The two scales, Being Bullied and Being the Bully, of the Olweus survey were comprised of 10 items each, and the scale values were created by summing the responses of all subscale items in the scale. Values on the two scales ranged from 0 to 40; the higher the scale score the more the respondent was Being Bullied or engaged in Being the Bully. The subscale items were questions that described the types of bullying (e.g., teasing, exclusion, kicking, hitting, etc.). Two sample survey items from the Being Bullied scale are (a) "I was hit, kicked, pushed, shoved around, or locked indoors" and (b) "I was bullied with mean names or comments about my race or color." For the dataset, the Being Bullied scale yielded a Cronbach's alpha of .87 and the Being the Bully scale had an alpha of .88, indicating good internal consistency among the items of both scales.

\section{Results}

We found significant differences in the mean Being Bullied scale scores between the independent variable categories of gender, years attending a Christian school, and division (but not grade). No significant relationships were noted for the scale of Bullying Others. There were also significant relationships for the kinds of bullying, its location, and the reporting of being bullied.

\section{Gender}

We found that the mean Being Bullied score, a measure of the frequency of being bullied, was statistically higher for girls $(M=15.05, S D=6.04)$ than boys $(M=13.40, S D=5.38), t(327)=2.63, p$ $<.01$. The types of bullying that girls reported more than boys were (a) being left out on purpose or ignored, $t(343)=3.23, p<.001$; (b) having false rumors spread about them (gossip), $t(294)=2.49, p<$ .05 ; (c) having names, comments, or gestures of a sexual nature directed at them, $t(294)=2.17, p<$ .05 ; and (d) being bullied through phone calls or the Internet (cyberbullying), $t(281)=2.82, p<.01$. Boys reported being hit, kicked, or pushed, physical forms of bullying, with significantly more frequency than girls, $t(242)=3.09, p<.05$. 
Table 1: Participant Profile by Gender ( $\mathrm{N}=347)$

\begin{tabular}{|c|c|c|c|c|c|c|}
\hline & \multicolumn{2}{|c|}{ Male } & \multicolumn{2}{|c|}{ Female } & \multicolumn{2}{|c|}{ Gender total } \\
\hline & Frequency & Percentage & Frequency & Percentage & Frequency & Percentage \\
\hline Gender $^{\mathrm{a}}$ & 190 & $54.8 \%$ & 156 & $45.0 \%$ & 346 & $99.7 \%$ \\
\hline \multicolumn{7}{|c|}{ Division $^{b}$} \\
\hline $\begin{array}{l}\text { Elementary } \\
\text { total }\end{array}$ & 33 & $49.3 \%$ & 34 & $50.7 \%$ & 67 & $19.3 \%$ \\
\hline Grade 3 & 12 & $17.9 \%$ & 11 & $16.4 \%$ & & \\
\hline Grade 4 & 11 & $16.4 \%$ & 9 & $13.4 \%$ & & \\
\hline Grade 5 & 10 & $14.9 \%$ & 14 & $20.9 \%$ & & \\
\hline $\begin{array}{l}\text { Middle school } \\
\text { total }\end{array}$ & 70 & $55.6 \%$ & 56 & $44.4 \%$ & 126 & $36.3 \%$ \\
\hline Grade 6 & 21 & $16.7 \%$ & 13 & $10.3 \%$ & & \\
\hline Grade 7 & 19 & $15.1 \%$ & 18 & $14.3 \%$ & & \\
\hline Grade 8 & 30 & $23.8 \%$ & 25 & $19.8 \%$ & & \\
\hline $\begin{array}{l}\text { High school } \\
\text { total }\end{array}$ & 87 & $56.9 \%$ & 66 & $43.1 \%$ & 153 & $44.1 \%$ \\
\hline Grade 9 & 43 & $28.1 \%$ & 41 & $26.8 \%$ & & \\
\hline Grade 10 & 44 & $28.8 \%$ & 25 & $16.3 \%$ & & \\
\hline \multicolumn{7}{|c|}{ Ethnicityc } \\
\hline Total & 186 & $55.0 \%$ & 152 & $45.0 \%$ & 338 & $97.4 \%$ \\
\hline $\begin{array}{l}\text { American } \\
\text { Indian }\end{array}$ & 2 & $.6 \%$ & 3 & $.9 \%$ & & \\
\hline $\begin{array}{l}\text { African } \\
\text { American }\end{array}$ & 8 & $2.4 \%$ & 8 & $2.4 \%$ & & \\
\hline $\begin{array}{l}\text { Arab } \\
\text { American }\end{array}$ & 7 & $2.1 \%$ & 1 & $.3 \%$ & & \\
\hline $\begin{array}{l}\text { Hispanic } \\
\text { American }\end{array}$ & 4 & $1.2 \%$ & 1 & $.3 \%$ & & \\
\hline $\begin{array}{l}\text { Asian } \\
\text { American }\end{array}$ & 7 & $2.1 \%$ & 6 & $1.8 \%$ & & \\
\hline $\begin{array}{l}\text { European } \\
\text { American }\end{array}$ & 126 & $37.3 \%$ & 119 & $35.2 \%$ & & \\
\hline Don't know & 32 & $9.5 \%$ & 14 & $4.1 \%$ & & \\
\hline \multicolumn{7}{|c|}{ Years in a Christian Schoold } \\
\hline Total & 187 & $54.7 \%$ & 155 & $45.3 \%$ & 342 & $98.6 \%$ \\
\hline 1 year & 20 & $5.8 \%$ & 21 & $6.1 \%$ & & \\
\hline $2-3$ years & 38 & $11.1 \%$ & 30 & $8.8 \%$ & & \\
\hline 4-6 years & 57 & $16.7 \%$ & 42 & $12.3 \%$ & & \\
\hline $7-9$ years & 44 & $12.9 \%$ & 47 & $13.7 \%$ & & \\
\hline $10+$ years & 28 & $8.2 \%$ & 15 & $4.4 \%$ & & \\
\hline
\end{tabular}

${ }^{a}$ Missing gender for one participant. ${ }^{b}$ Missing division for one participant. ${ }^{c}$ Missing ethnicity for nine participants. ${ }^{\mathrm{d}}$ Missing years in a Christian school for five participants.

In a $2 \times 2$ chi-square analysis, we found a significant association between the gender of the bully and the gender of the student being bullied, $\chi^{2}(1)=43.23, p<.001$. Girls were twice as likely to be bullied by another girl as a boy, and boys were 8 times more likely to be bullied by another boy than a girl. In terms of bullying others, male and female students reported never having bullied someone else at similar rates. However, in terms of bullying two to three times a month or more, boys acknowledged being perpetrators at double the rate of girls. 


\section{Grade and Division}

Bullying was reported most frequently at the lower grades. For example, only $25 \%$ of the fourth graders reported that they had not been bullied over the previous 2 months, but twice as many students (approximately 50\%) in eighth and in ninth grade reported that they had not been bullied. With just two exceptions, bullying decreased as grade increased. There was a slight increase in bullying between the third and fourth grades, and a marked increase in sixth grade. Nonetheless, differences in the mean Being Bullied scale scores among the various grades were not significant $(p=$ $.052)$.

In elementary school, $61.2 \%$ of the students reported being bullied, while $54.8 \%$ of middle school students reported being bullied. The least amount of bullying was reported by high school students (43.5\%). We also conducted a one-way analysis of variance (ANOVA) to test the effect of school division on the scale Being Bullied and found there was a significant effect, $F(2,327)=3.21, p<.05$. Post hoc comparisons using the Games-Howell procedure indicated that the mean score of Being Bullied for elementary students $(M=15.52, S D=5.56)$ was significantly higher than for high school students $(M=13.39, S D=5.05)$.

\section{Years in a Christian School}

According to our data, the highest mean score on both scales, Being Bullied ( $M=14.91, S D=6.79)$ and Being the Bully $(M=14.37, S D=7.98)$, occurred in students who were in the Christian school for 4-6 years. A one-way ANOVA to test the effect of years in a Christian school and the scale Being the Bully yielded a significant overall effect, $F(4,321)=2.49, p<.05$. However, post hoc analysis using the Games-Howell procedure did not detect which groups were significantly different, although the largest difference between means (i.e., greater than 2 points on the scale) occurred between 4-6 years and 7-9 years and between 4-6 years and 10 or more years. The mean scores of the frequency of being the bully gradually increased from 1 year to $2-3$ years of attendance in a Christian school and then peaked at 4-6 years, gradually decreasing thereafter at 7-9 years and even more so at 10 or more years of attending a Christian school. A similar trend in the mean scores occurred with Being Bullied and years in a Christian school; however, a significant overall main effect was not detected by a one-way ANOVA.

We conducted another one-way ANOVA to test the effect of years in a Christian school on the types of bullying which students used to bully another student and found significant overall effects for spreading false rumors (gossip), $F(4,335)=2.37, p<.05$, and using names or comments about other students' race or color (racist comments), $F(4,333)=2.84, p<.05$. (A third type of bullying, making fun and teasing in a hurtful way, yielded a $p$ value of .0507 , which was extremely close to being statistically significant.) Post hoc analysis using the Games-Howell procedure showed that students attending a Christian school for $4-6$ years $(M=1.25, S D=0.91)$ used racist comments significantly more than students who had been attending a Christian school for 10 or more years $(M=1.00, S D=$ 0.00). Despite a significant overall effect, post hoc analysis did not reveal any groups that were

significantly different for the gossip variable; however, the largest mean difference was between students attending a Christian school for $4-6$ years $(M=1.32, S D=0.89)$ and 10 or more years $(M=$ $1.07, S D=0.34)$. 


\section{Location and Reporting of Bullying}

Table 2 presents the location where students from each school division reported that they were bullied. Elementary students reported being bullied more frequently outside the school building than middle school or high school students (i.e., on the playground/field, on the way to/from school, at the school bus stop, and on the school bus). Middle school and high school students reported being bullied more frequently inside the school building than elementary school students (i.e., hallway/stairs, in class with and without teacher, and in gym class/locker room). The two exceptions are in the bathroom where elementary school students are bullied more, and in the lunchroom where students reported being bullied about equally across school divisions.

Table 2: Location Where Students Reported Being Bullied by School Division

\begin{tabular}{lccccccc}
\hline & \multicolumn{2}{c}{ Elementary school } & \multicolumn{2}{c}{ Middle school } & \multicolumn{2}{c}{ High school } & \\
\cline { 2 - 6 } & Frequency & Percentage & Frequency & Percentage & Frequency & Percentage & Total \\
\hline Playground/field & 34 & $55.7 \%$ & 14 & $23.0 \%$ & 13 & $21.3 \%$ & 61 \\
$\begin{array}{l}\text { Hallway/stairs } \\
\text { In class with }\end{array}$ & 11 & $12.0 \%$ & 41 & $44.6 \%$ & 40 & $43.5 \%$ & 92 \\
$\quad$ teacher & 20 & $29.4 \%$ & 24 & $35.3 \%$ & 24 & $35.3 \%$ & 68 \\
$\quad \begin{array}{l}\text { In class without } \\
\text { teacher }\end{array}$ & 16 & $25.0 \%$ & 25 & $39.1 \%$ & 23 & $35.9 \%$ & 64 \\
$\quad \begin{array}{l}\text { In the bathrooms } \\
\text { In gym class/locker }\end{array}$ & 11 & $47.8 \%$ & 5 & $21.7 \%$ & 7 & $30.4 \%$ & 23 \\
$\quad$ room & 10 & $21.3 \%$ & 21 & $44.7 \%$ & 16 & $34.0 \%$ & 47 \\
$\quad \begin{array}{l}\text { In the lunchroom } \\
\text { On way to/from }\end{array}$ & 25 & $34.2 \%$ & 26 & $35.6 \%$ & 22 & $30.1 \%$ & 73 \\
$\quad$ school & 7 & $46.7 \%$ & 3 & $20.0 \%$ & 5 & $33.3 \%$ & 15 \\
$\quad \begin{array}{l}\text { At the school bus } \\
\text { stop }\end{array}$ & 3 & $50.0 \%$ & 1 & $16.7 \%$ & 2 & $33.3 \%$ & 6 \\
On the school bus & 13 & $65.0 \%$ & 5 & $25.0 \%$ & 2 & $10.0 \%$ & 20 \\
\hline
\end{tabular}

Table 3 presents information on whom students told about being bullied for each school division. In a $2 \times 3$ chi-square analysis, we found a significant association between those students who reported bullying and school division, with elementary students reporting bullying more frequently than either middle or high school students, $\chi^{2}(2, N=157)=14.76, p<.001$. Elementary students were more likely to tell a teacher, parent, or sibling than middle or high school students. In fact, no high school student reported telling a teacher that he or she was bullied. As students move from elementary to middle to high school, they are more likely to confide in a friend about being bullied. Additionally, students are equally likely to tell an adult in the school, who is not their teacher, about being bullied. Finally, on the survey, $9.0 \%$ of elementary school students, $19.2 \%$ of middle school students, and $15.8 \%$ of high school students reported that they were bullied, but never told anyone about it.

In $2 \times 2$ chi-square analyses with Yates' continuity correction, we found significant associations between the location where the student was bullied and who they told. In fact, of the significant chisquare analyses, the teacher was told in every case. Students who reported being bullied on the playground or field were 5.2 times more likely to report it to a teacher than not report it at all, $\chi^{2}(1$, $N=90)=15.61, p<.001$. Students who reported being bullied in the bathroom were 6.6 times more 
likely to report it to a teacher than not report it at all, $\chi^{2}(1, N=90)=8.25, p<.01$. Finally, students who were bullied in the lunchroom were 3.4 times more likely to report it to a teacher than not report it at all, $\chi^{2}(1, N=90)=4.76, p<.05$.

Table 3: Whom Students Told About Being Bullied by School Division

\begin{tabular}{lccccccc}
\hline & \multicolumn{2}{c}{ Elementary school } & \multicolumn{2}{c}{ Middle school } & \multicolumn{2}{c}{ High school } & \\
\cline { 2 - 7 } & Frequency & Percentage & Frequency & Percentage & Frequency & Percentage & Total \\
\hline Teacher & 19 & $73.1 \%$ & 7 & $26.9 \%$ & 0 & $0.0 \%$ & 26 \\
School & 12 & $33.3 \%$ & 12 & $33.3 \%$ & 12 & $33.3 \%$ & 36 \\
$\quad$ adult & & & & & & & \\
Parent & 30 & $41.7 \%$ & 17 & $23.6 \%$ & 25 & $34.7 \%$ & 72 \\
Brother & 13 & $46.4 \%$ & 5 & $17.9 \%$ & 10 & $35.7 \%$ & 28 \\
$\begin{array}{c}\text { or sister } \\
\text { Friend }\end{array}$ & 22 & $30.6 \%$ & 24 & $33.3 \%$ & 26 & $36.1 \%$ & 72 \\
\hline
\end{tabular}

\section{Attitude Toward School}

One final analysis we conducted was a logistic regression to test whether Being Bullied predicted whether a student liked or disliked school. Regression results indicated the overall model was statistically reliable in distinguishing between whether a student would like or dislike school $(-2 \log$ likelihood = 267.76; Hosmer-Lemeshow goodness-of-fit $=4.07, d f=5, p=.54), \chi^{2}(1, N=228)=16.63$, $p<.001$. The model correctly classified $72.4 \%$ of the cases. Table 4 shows the regression coefficients. According to the Wald criterion, Being Bullied significantly predicted whether a student would like school $(p<.001)$, or because the $B$ value is negative, we can say that an increase in Being Bullied predicted a greater likelihood of disliking school. However, the odds ratio of .91 shows little change in the likelihood of disliking school on the basis of just a 1-unit change on the scale of Being Bullied, which ranges from 0 to 40 .

Table 4: Logistic Regression Analysis of Liking/Disliking School as a Function of Being Bullied

\begin{tabular}{|c|c|c|c|c|c|c|}
\hline \multirow[b]{2}{*}{ Variables } & \multirow[b]{2}{*}{$B$} & \multirow[b]{2}{*}{$S E$} & \multirow{2}{*}{$\begin{array}{c}\text { Wald } \\
\chi^{2}\end{array}$} & \multirow{2}{*}{$\begin{array}{l}\text { Odds } \\
\text { ratio }\end{array}$} & \multicolumn{2}{|c|}{$\begin{array}{l}95 \% \text { Confidence interval } \\
\text { for odds ratio }\end{array}$} \\
\hline & & & & & Lower & Upper \\
\hline Being bullied & -0.10 & .03 & 13.87 & 0.91 & .86 & .96 \\
\hline (Constant) & 2.20 & .41 & 28.77 & & & \\
\hline
\end{tabular}




\section{Discussion}

The purpose of this study was to explore the extent and nature of bullying within the context of a Christian school. Gender and grade have been shown by other studies to be related to bullying behaviors, but no studies were found that examined bullying within the context of a Christian school. SIT suggests that behaviors change to accommodate the values of the prevailing group culture. We were, therefore, particularly interested to see whether years attending the Christian school would affect bullying.

\section{Gender}

We found that there was a significant difference in the incidence of bullying between males and females, with girls reporting being bullied more frequently than boys. There are also differences in the specific types of bullying experienced by each gender in the Christian school. Girls experienced more exclusion, rumors, sexual comments, and cyberbullying. Boys endured more physical forms of bullying. These findings are consistent with previous studies that found girls to be more likely to use relational aggression such as gossip, rumor, exclusion, and manipulation of friendships while boys were more prone to violence (Borg, 1999; Gabel, 2007; Olweus, 2003; Seals \& Young, 2003).

Although boys were more likely to use physical forms of bullying, in general physical bullying in the Christian school was rare. Furthermore, physical bullying was among the least prevalent forms of bullying in the Christian school with over $90 \%$ of the students reporting no incidents in the past couple of months, and $6.1 \%$ reporting that it had occurred only once or twice. By comparison, Cardoso (2007) found that 51.3\% of public school students had never been physically bullied and $31.7 \%$ who indicated that it had happened only once or twice. Although it was not possible to determine whether the differences in percentages between Cardoso's and our study were statistically significant, the differences were quite large nonetheless, with the Christian school students experiencing less physical forms of bullying than public school students.

According to Gabel (2007) girls are bullied equally by boys and girls; however, in this setting, girls were twice as likely to be bullied by other girls than by boys. Put another way, boys were half as likely to bully girls as girls were to bully girls. It is not clear why this difference exists. We theorize that it may have to do with the presence of more traditional gender roles within the Christian community that may lead to an expectation that males are to protect females.

\section{Grade and Division}

In contrast to most studies, we found that bullying in the Christian school declined steadily as students moved through the divisions from elementary to high school. We did not establish any causal relationships, but there is a noticeable trend of a decrease in bullying as students progress through school. Indeed, if parents and teachers are effectively training students and developing their character, then we would expect to see growth in self-control and concern for others as students mature. This trend is striking because it runs counter to the prevailing research. SIT would explain that this is the result of an effective school culture that increasingly encourages compassion for others and suppresses bullying behaviors. We were not able to establish a causal link or separate the influence of parents from that of the school. However, in an effort to further examine the role of the school, we examined the relationship between bullying and years attending the Christian school. 


\section{Years in a Christian School}

Our research did not confirm a relationship between being bullied and years attending the Christian school. It did, however, determine that there was a relationship between being a bully and years attending. Unfortunately, we were not able to establish which grade division was significantly different. An examination of the means indicates that bullying increases in the initial years of attending a Christian school and then declines after that. Nevertheless, it is difficult to account for this pattern. One can speculate that there might be some increase in the incidence of bullying with students who are new to the school, but one would expect that trend to disappear after the first year. Perhaps, it takes 4-6 years for the culture of a school to fully impact students, and only after that does a decline set in; however, that does not explain the increase over the first 1-3 years. At this point, the most we can say is that there does seem to be a connection between bullying and years attending a Christian school, but the nature of that connection is not clear.

There was also a relationship between the kinds of bullying and years attending the Christian school in regards to spreading rumors and racist comments. Further analysis failed to reveal the nature of this relationship. We believe that the size of this study limited our ability to find relationships and patterns that statistical tests show do exist.

\section{Location and Reporting of Bullying}

The location of bullying follows a fairly clear pattern with elementary students typically being bullied more outside of the school building and middle and high school students being bullied more on the inside (see Table 2). We believe that this pattern is simply a result of the nature of school life for students at these grades. Elementary students use the playground for socializing, and upper grades students tend to cluster in the halls and stair wells. In this particular school, only elementary students rode a shuttle bus to their campus, and all middle and high school students were either driven by parents or drove themselves. While these differences are easily explained, they are not unimportant. School officials should make use of this kind of information to ensure that supervision is appropriate to the location where bullying is most likely to occur given the age level of the students.

The person to whom students in the Christian school report bullying changes with age (see Table 3). Elementary students are much more likely to report to a teacher, but not one high school student indicated that they had reported to a teacher. Generally, as students mature, it is to be expected and even hoped for that they would resolve problems by themselves or perhaps with the aid of a friend rather than resorting to an authority figure. Students who were bullied in bathrooms, lunchrooms, or the playgrounds were much more likely to report it to a teacher than anyone else. We did not anticipate this finding, but we surmise that students view these areas as under the purview of teachers more than anyone else, and so report to them. When incidents occur on a bus or the Internet, it is not as clearly a teacher's responsibility. Nevertheless, it should also be noted that some bullying that occurs in schools is never reported to anyone, but if it is reported, teachers of high school students will be the least likely to hear about it. 


\section{Attitude Toward School}

It should come as no surprise that being bullied has an impact on a student's attitude toward school. We found a clear relationship between a higher incidence of being bullied and a greater dislike of school. Students who felt threatened and unsafe at school due to the presence of bullies began to develop negative attitudes toward school. These negative attitudes may eventually impact student behavior or academic achievement.

\section{Conclusion}

The results of this preliminary investigation provided insight into the extent and nature of bullying within the Christian school environment. We found that, for the most part, the patterns of bullying in the Christian school are similar to those found in schools around the world. As in many schools, boys more frequently experienced the more obvious physical forms of bullying, and girls are more frequently victimized with a variety of forms including exclusion, rumors, sexual comments, and cyberbullying. We also confirmed that there are distinct patterns of bullying behaviors that are related to gender regardless of school environment. This finding can be used to promote positive social change by alerting school educators to the problem of bullying in their schools, and by assisting educators in developing gender-specific programs or interventions geared toward minimizing the problem of bullying.

However, there are also some striking differences that became apparent through this study. Our results suggest that bullying in a Christian school takes notably less physically aggressive forms. It is difficult to determine exactly why this is, but this fact alone is worthy of additional research in order to determine whether the school is a primary factor. The fact that girls were much less likely to be bullied by boys than is typical in other schools suggests that the socializing process among boys seems to be more successful in this environment. We have not established a causal link at this time, but the data indicate that this trend is worthy of further investigation.

The presence of statistically significant relationships between bullying and years attending a Christian school was a tantalizing finding. Our inability to describe these relationships in more detail is likely due to the small size of our study. Future studies with larger numbers of students may well demonstrate differences in the incidence of bullying for the number of years attending a Christian school as social identity and moral development theories would suggest.

\section{References}

Basset, W. P., \& Baumann, E. K. (2003). Teaching methodologies. In J. Braley, J. Layman, \& R. White (Eds.), Foundations of Christian school education (pp. 121-144). Colorado Springs, CO: Purposeful Design Publications.

Battistich, V. A. (2008). Voices: A practitioner's perspective. Journal of Research in Character Education, 6, 81-90. Retrieved from http://www.infoagepub.com/research-in-charactereducation

Beaty, L., \& Alexeyev, E. (2008). The problem of school bullies: What the research tells us. Adolescence, 43, 1-11.

Borg, M. G. (1999). The extent and nature of bullying among primary and secondary schoolchildren. Educational Research, 41, 137-153. doi:10.1080/0013188990410202 
Braley, J. (1995). Christian school and society. In P. A. Kienel, O. E. Gibbs, \& S. R. Berry (Eds.), Philosophy of Christian school education (pp. 433-455). Colorado Springs, CO: Association of Christian Schools International.

Brown, G. (1995). Christian purposes and goals of education. In P. A. Kienel, O. E. Gibbs, \& S. R. Berry (Eds.), Philosophy of Christian school education (pp. 131-154). Colorado Springs, CO: Association of Christian Schools International.

Cardoso, A. (2007). An analysis of bullying in a large, urban school district. (Doctoral dissertation). Retrieved from ProQuest Dissertations \& Theses database. (AAT 3293203).

Craig, W., Harel-Fisch, Y., Fogel-Grinvald, H., Dostaler, S., Hetland, J., Simons-Morton, B., . . HBSC Bullying Writing Group. (2009). A cross-national profile of bullying and victimization among adolescents in 40 countries. International Journal of Public Health, 54, 216-224. doi:10.1007/s00038-009-5413-9

Craig, W. M., \& Pepler, D. J. (2007). Understanding bullying: From research to practice. Canadian Psychology, 48, 86. doi:10.1037/cp2007010

Dake, J. A., Price, J. H., \& Telljohann, S. K. (2003). The nature and extent of bullying at school. Journal of School Health, 73, 173-180. doi:10.1111/j.1746-1561.2003.tb03599

Delfabbro, P., Winefield, T., Trainor, S., Dollard, M., Anderson, S., Metzer, J., \& Hammarstrom, A. (2006). Peer and teacher bullying/victimization of South Australian secondary school students: Prevalence and psychosocial profiles. British Journal of Educational Psychology, 76, 71-90. doi:10.1348/ 000709904X24645

DeVoe, J. F., Peter, K., Noonan, M., Snyder, T. D., \& Baum, K. (2005). Indicators of school crime and safety: 2005 (NCES 2006-001/NCJ 210697). Washington, DC: U.S. Departments of Education and Justice, U.S. Government Printing Office.

Duffy, A. L., \& Nesdale, D. (2009). Peer groups, social identity, and children's bullying behavior. Social Development, 18, 121-139. doi:10.1111/j.1467-9507.2008.00484.x

Edlin, R. (2003). Core beliefs and values of a Christian philosophy of education. In J. Braley, J. Layman, \& R. White (Eds.), Foundations of Christian school education (pp. 67-81). Colorado Springs, CO: Purposeful Design Publications.

Fox, J. A., Elliott, D. S., Kerlikowske, R. G., Newman, S. A., \& Christeson, W. (2003) Bullying prevention is crime prevention. Washington, DC: Fight Crime: Invest in Kids. Retrieved from http://www.fightcrime.org/state/usa/reports/bullying-prevention-crime-prevention-2003

Gabel, E. P. (2007). The prevalence and impact of bullying behaviors on middle and high school students: Grade, gender and ethnic differences. (Doctoral dissertation). Retrieved from ProQuest Dissertations and Theses. (AAT 3287154)

Harlow, K. C., \& Roberts, R. (2010). An exploration of the relationship between social and psychological factors and being bullied. Children \& Schools, 32, 15-26. doi:10.1093/cs/32.1.15

Hollingshead, B., Crump, C., Eddy, R., \& Rowe, D. (2009). Rachel's challenge: A moral compass for character education. Kappa Delta Pi Record, 45, 111-115. doi:10.1080/00228958.2009.10517299

Hunter, S. C., Boyle, J. M., \& Warden, D. (2004). Help seeking amongst child and adolescent victims of peer-aggression and bullying: The influence of school-stage, gender, victimisation, appraisal, and emotion. British Journal of Educational Psychology 74, 375-390. doi:10.1348/0007099041552378 
Lansford, J. E., Skinner, A. T., Sorbring, E., Giunta, L., Deater-Deckard, K., Dodge, K. A., \& Chang, L. (2012). Boys' and girls' relational and physical aggression in nine countries. Aggressive Behavior, 38, 298-308. doi:10.1002/ab.21433

Lee, K. (2003). School bullying in Korea and Christian educational approach. Asia Pacific Education Review, 4, 75-83. Retrieve from http://eri.snu.ac.kr/aper/index.html

Lickona, T. (2004). Character matters: How to help our children develop good judgment, integrity, and other essential virtues. New York, NY: Simon \& Schuster.

Long, T., \& Alexander, K. (2010). Bullying: Dilemmas, definitions, and solutions. Contemporary Issues in Education Research, 3, 29-34. Retrieve from http://journals.cluteonline.com/index.php/CIER/index

Oh, I., \& Hazler, R. J. (2009). Contributions of personal and situational factors to bystanders' reactions to school bullying. School Psychology International, 30, 291-310. doi:10.1177/0143034309106499

Olweus, D. (2003). A profile of bullying at school. Educational Leadership, 60, 12. Retrieved from http://www.ascd.org/publications/educational-leadership.aspx

Olweus, D. (2007). Olweus Bullying Questionnaire. Center City, MN: Hazelden Publishing.

Olweus, D. (2013). School bullying: Development and some important challenges. Annual Review of Clinical Psychology, 9, 751-780. doi:10.1146/annurev-clinpsy-050212-185516

Pepler, D., Craig, W. M., Connolly, J. A., Yuile, A., McMaster, L., \& Jiang, D. (2006). A developmental perspective on bullying. Aggressive Behavior, 32, 376-384. doi:10.1002/ab.20136

Porter, J. (2009). Children's tendency to defend victims of school bullying: Gender, social identity, and normative pressure (Doctoral dissertation). Retrieved from ProQuest Dissertations \& Theses database. (AAT 3367575)

Salmivalli, C., \& Voeten, M. (2004). Connections between attitudes, group norms, and behavior in bullying situations. International Journal of Behavioral Development, 28, 246-258. doi:10.1080/01650250344000488

Schindler, C. (1995). School atmosphere and relationships. In P. Kienel, O. Gibbs, \& Berry, S. (Eds.), Philosophy of Christian school education (pp. 413-432). Colorado Springs, CO: Association of Christian Schools International.

Seals, D., \& Young, J. (2003). Bullying and victimization: Prevalence and relationship to gender, grade level, ethnicity, self-esteem, and depression. Adolescence, 38, 735-747.

Stronk, G. G. (2003). The nature of the learner. In J. Braley, J. Layman, \& R. White (Eds.), Foundations of Christian school education (pp. 85-98). Colorado Springs, CO: Purposeful Design Publications.

Theriot, M. T., Dulmus, C. N., Sowers, K. M., \& Bowie, S. L. (2004). The criminal bully linking criminal peer bullying behavior in school to a continuum of delinquency. Journal of EvidenceBased Social Work, 1, 77-92. doi:10.1300/ J394v01n01_02

Whitted, K. S., \& Dupper, D. R. (2005). Best practices for preventing or reducing bullying in schools. Children \& Schools, 27, 167-175. doi:10.1093/cs/27.3.167

Zigarelli, M. (2002). Cultivating Christian character: How to become the person God wants you to be and how to help others to do the same. Fairfax, VA: Xulon Press. 
The Journal of Educational Research and Practice provides a forum for studies and dialogue that allows readers to better develop social change in the field of education and learning. Journal content may focus on educational issues of all ages and in all settings. It also presents peer-reviewed commentaries, book reviews, interviews of prominent individuals, and additional content. The objectives: We publish research and related content that examines current relevant educational issues and processes aimed at presenting readers with knowledge and showing how that knowledge can be used to impact social change in educational or learning environments. Additional content provides an opportunity for scholarly and professional dialogue regarding that content's usefulness in expanding the body of scholarly knowledge and increasing readers' effectiveness as educators. The journal also focuses on facilitating the activities of both researcher-practitioners and practitioner-researchers, providing optimal opportunities for interdisciplinary and collaborative thought through blogging and other communications.

Walden University Publishing: http://www.publishing.waldenu.edu 